\title{
Phenotypic Response of Rice Genotypes Under Submergence Conditions at Seedling Stage
}

\author{
Mubashar Hussain ${ }^{1 *}$, Umar Niaz ${ }^{2}$, Muhammad Bilal' ${ }^{2}$ and Nauman Liaqat ${ }^{3}$ \\ ${ }^{1}$ Rice Research Institute Kala Shah Kaku, Pakistan
}

${ }^{2}$ Department of Entomology, Pakistan

${ }^{3}$ Department of Agronomy, Pakistan

Received: 眥 November 28, 2018; Published: 啡 December 05, 2018

*Corresponding author: Mubashar Hussain, Rice Research Institute Kala Shah Kaku, Lahore, Pakistan

\begin{abstract}
Screening of twenty rice varieties with sub1 gene was performed to check their resistance under submergence conditions. This experiment involved growing of rice germ plasms sown in small pots filled with Irish Peat Moss. These pots were placed in incubator for germination. After ten days these pots were submerged in water tank to check their submergence resistance. Three varieties showed good tolerance against submergence as they grew less in length and seventeen varieties gave poor result as they grew more in length.
\end{abstract}

\section{Introduction}

Rice (Oryza sativa) is second major cereal crop in world [1]. Seventy percent population of world depends on agriculture as a source of living. Agriculture is leading sector in many countries of the world. It is main source of thousands of jobs and income in these countries [2]. Rice is staple food of half population of world. $90 \%$ of rice produced worldwide is consumed in South Asia. There are chances that climate change can bring positive influence on agriculture, but negative influence mostly dominates [3]. In South Asia Pakistan is mostly exposed to climate change. Pakistan was marked as third most exposed country to climate change out of 128 countries of the world as said by German Watch Report (2011) respectively Adeel et al., 2017. There are two types of stresses biotic and abiotic. Submergence is one of the major abiotic stresses. Cultivated varieties are less tolerant to water submergence stress because of their poor grain quality, droopy leaves and tillering ability. There is utmost need to develop submergence tolerant varieties Fahim et al., 2016. Plants require water for their growth but in excess amount like submergence and water logging is extremely injurious to plants Shunsaku et al., 2012.

Flash flooding causing submergence of rice plants for 1015 days is one of the major problems in rice growing rain fed lowland areas of South Asia Manzoor et al., 2017. Rainfed and lowland rice are $33 \%$ of total rice farmlands in world. Almost $66 \%$ of rice land of shallow and intermediate rainfed lowlands is present in Bangladesh, Pakistan, India and Thailand. Some other countries with high percentage of rainfed lowlands areas are Nepal, Myanmar, Laos and Combodia Julia et al., 2010. Rice is grown in twelve million hectares of land that is prone to flood in Southeast and South Asia. Where flood water covers land from depth of $50 \mathrm{~cm}$ to $2 \mathrm{~m}$ [3]. Pakistan faced huge losses in rice yield due to flash flooding during the period of 2010-2014. Genetic control of submergence remained debatable till 1990s. Many studies gave idea that it was quantitative trait $[4,5]$. Sub1 was identified on chromosome 9 by molecular mapping. It showed that it contributes $70 \%$ of phenotypic variation in tolerance [6]. Many other studies identified chromosome 9 QTL as major and also confirmed many other QTLs that were $30 \%$ of phenotypic variation in tolerance [7]. Comprehensive analysis of many rice accessions with different sub1 genes showed that submergence tolerance is linked with different levels of sub1 transcript at nodes and internodes at the time when plant starts heading [8]. Submergence puts plant under severe and complex abiotic stress [9]. Severances of injury imposed by submergence depends at the nature of flood, factors include its turbidity temperature and light penetration [10]. Major drawback of submergence is reduction in photosynthesis and respiration [11]. When flood is prolonged, and plant is submerged deep then protection of energy reserves is advantageous [12]. Accumulation of sub1A mRNA is done by ethylene [11,12]. Ethylene exposure promotes the activity of sub1A that restricts the gibberellic acid 
induced increase in growth as a result food reserves of plant are protected, and It does not lodge when water level comes down $[11,12]$.

\section{Material and Methods}

24 genotypes of rice were selected for submergence screening at seedling stage at Rice Research Institute, Kala Shah Kaku. Their soaking was done in normal water at room temperature for 24 hours. To start germination of seeds, they were placed in 24 petri dishes [13-15]. Medium used for growth was wetted filter paper and were placed in incubator at 35 degree centigrade and relative humidity $14.25 \%$ for 2 days. It was followed by sowing of germinated seed in plastic pots filled with Irish peat moss and these plastic pots were placed in growth chamber for 2 weeks at 26 degree centigrade with photoperiod of 12 hours. Process included soaking of first 24 genotypes (Figure 1). After 24 hours of soaking they were placed in incubator for incubation and after the development of roots and shoots in incubator they were sown in plastic pots filled with Irish peat moss and were placed in growth chamber where their temperature and humidity was maintained, and they were also kept in sunlight at day time to fulfill their light requirement. Irrigation and fertigation was applied at regular interval according to the requirements of plants. After 14 days half genotypes were shifted to submergence tank with half as their control [16-18]. The ph. of water filled in tank was 6.7. Length of plants was measured before shifting to submergence tank and It was also measured after 2 days, 4 days and one week along with control plants. Arrangement of pots was in completely randomized design (Figure 2). To check tolerance of plants against water submergence they were placed in submergence tank for seven days. Survival of plants was observed after seven days of submergence (Figure 3). Height of plants was noted before and after submergence and also during the time of submergence with interval of two days (Table 1).

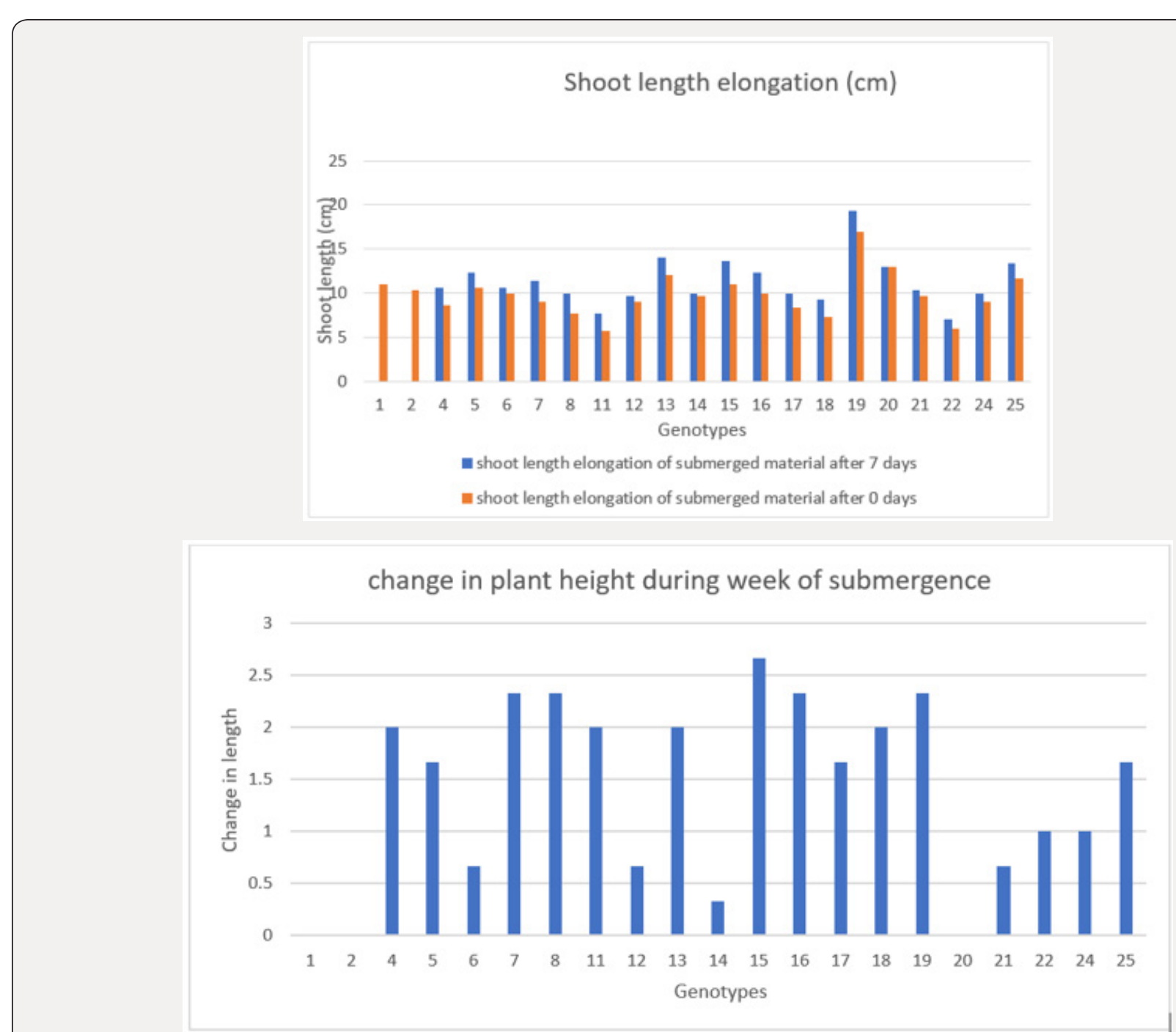

Figure 1: $1^{\text {st }}$ two genotypes cannot survive due to harsh environmental conditions and become dead and same in case of genotype no 20. While from others genotype no 14 shows less difference which is 0.35 and it is best performer in this experiment and genotype no 6,12 and 21 are at 2nd position and 21 genotypes is check variety, so they are also good performer but showing more difference then genotype 14 . While genotype 15, 7, 8, 16, 19 are bad performer because they show great differences in plant height and when de submergence occurs, they will lodge down and cause decrease in yield. 


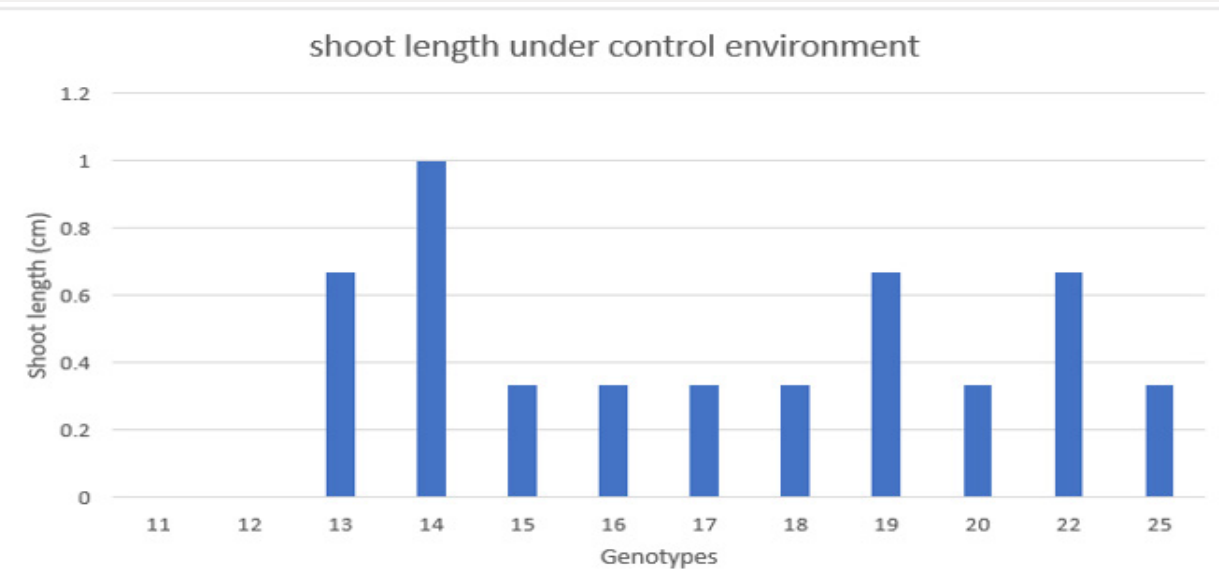

Figure 2: In case of control, genotype 11 and 12 cannot survive due to harsh environment conditions and become dead. Genotypes 15,16,17,18,20 and 25 shows 0.35 increase in length within a week while 14 genotypes get maximum height and genotype 13, 19 and 22 are in between performers of maximum and minimum.

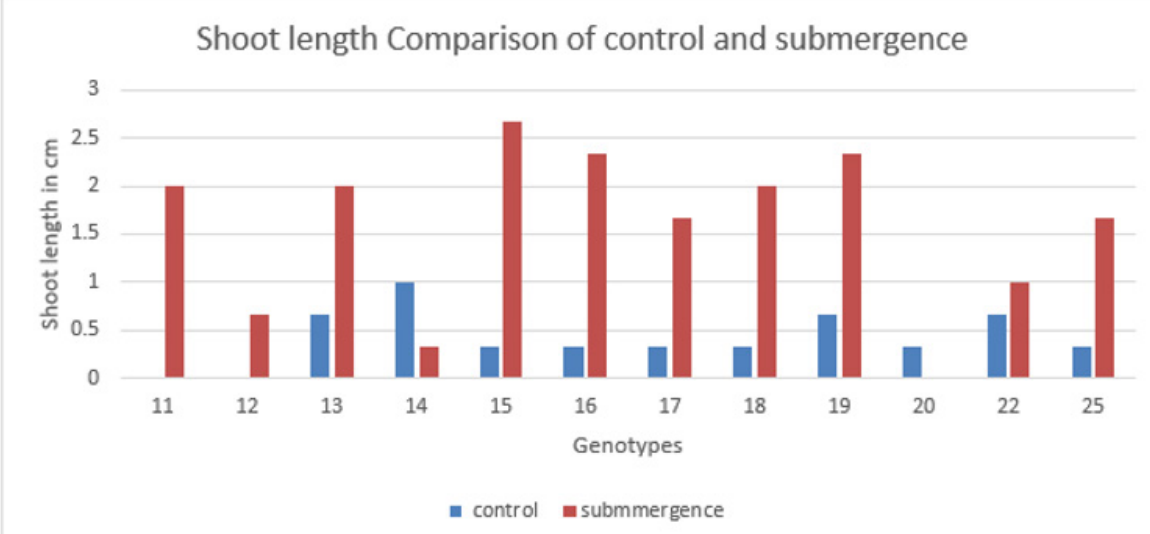

Figure 3: When we compare both cases of submergence as well as control, we get following results. In case of control, 11 and 12 genotypes are dead while in case of submergence $20^{\text {th }}$ genotype is dead, so we cannot compare these genotypes. From others, $14^{\text {th }}$ genotype gain more height in case of control comparing with submergence and other genotypes gain more height in case of submergence comparing with control. $12^{\text {th }}$ and $14^{\text {th }}$ genotypes are showing less height in submergence so they are good performers. While $17^{\text {th }}$ and $25^{\text {th }}$ genotypes can be used as submergence tolerance while genotypes $11^{\text {th }}, 13^{\text {th }}, 15^{\text {th }}, 16^{\text {th }}, 18^{\text {th }}, 19^{\text {th }}$ cannot be used as submergence tolerance due to more height..

Table 1: Material.

\begin{tabular}{|c|c|}
\hline Code No. & Variety name \\
\hline V1 & Bas 370 \\
\hline V2 & Bas 198 \\
\hline V3 & Bas Pak \\
\hline V4 & Bas 385 \\
\hline V5 & Super basmati \\
\hline V6 & Bas 2000 \\
\hline V7 & Basmati 515 \\
\hline V8 & Pk 386 \\
\hline V9 & PS 2 \\
\hline V10 & Kisan Basmati \\
\hline V11 & Chenab Basmati \\
\hline V12 & Punjab Basmati) \\
\hline
\end{tabular}




\begin{tabular}{|c|c|}
\hline V13 & PK 8892-4-2-1-1 \\
\hline V14 & PK 8892-4-1-3-1 \\
\hline V15 & PRI 3 \\
\hline V16 & PK BB15-1 \\
\hline V17 & PK BB15-6 \\
\hline V18 & PKBB8 \\
\hline V19 & PK 10355 \\
\hline V20 & Check susceptible \\
\hline V21 & Check susceptible \\
\hline V22 & Check tolerant \\
\hline V23 & Check tolerant \\
\hline V24 &
\end{tabular}

\section{Results and Discussion}

All genotypes showing increase in length within a week of submergence (Figure 4). Genotypes V7 and V8 gain maximum length within first week of submergence while Genotypes V4, V11, V13 and V18 responded with 2nd position in length increase within first week of submergence. While genotype 20 shows no change within this week of submergence. Check varieties showed increase in length with medium range. In addition, others were in between of these genotypes. It was observed that genotype V20 was the best for submergence tolerance because it showed no change in length within first week of submergence and genotypes V7 and V8 were found poor performers.

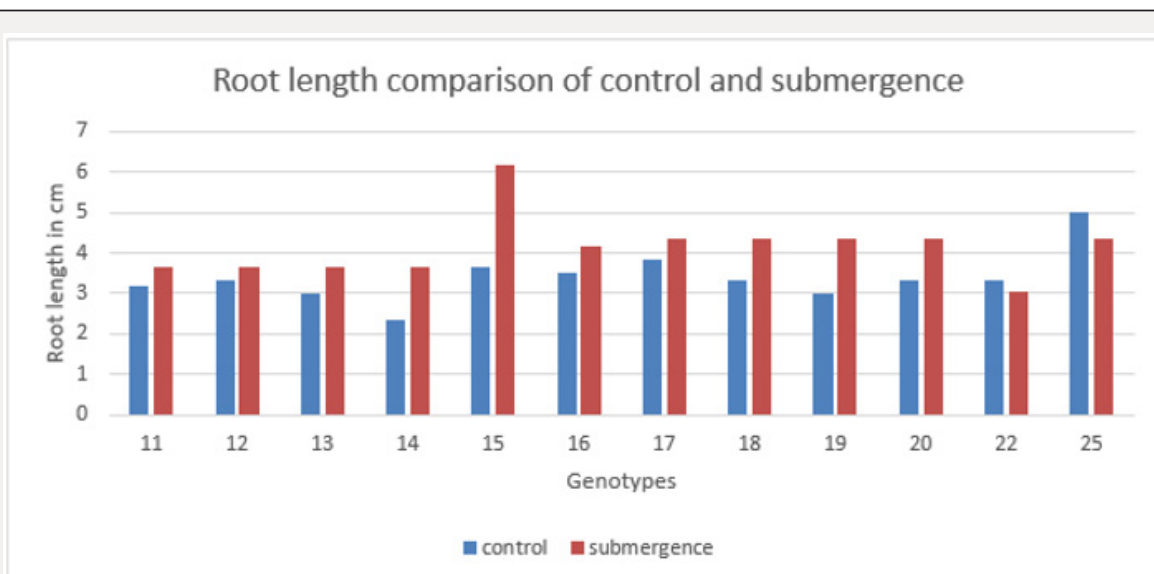

Figure 3: Only genotypes $20^{\text {th }}$ and $25^{\text {th }}$ root length is more in case of control than submergence while other all genotypes have more length attaining in case of submergence and $15^{\text {th }}$ genotype gets maximum root length. In both conditions of submergence as well as control, genotypes show significant results which show that they perform differently. Genotype 11 shows less plant height in both conditions of submerged as well as control and it is very near to check variety in case of performance under submergence and can be used as submergence tolerant. While genotype 19 shows very much growth in submerged condition and shows highest height while in case of control it is not so much vigor. So, we cannot use it as submergence tolerance because when de submergence occur it will lodge down and cause loss in yield. Other genotypes are in between of these two genotypes. Genotype 18 show same performance in case of both submergence and control so it can also be submergence tolerant.

\section{References}

1. Fukao T, Bailey Serres J (2008) Submergence tolerance conferred by Sub1A is mediated by SLR1 and SLRL1 restriction of gibberellins responses in rice. Proc Natl Acad Sci USA 105: 16814-16819.

2. Dar MH (2017) Transforming rice cultivation in flood prone coastal Odisha to ensure food and economic security. Food Security 9(4): 711722.

3. Sripongpangkul K, Posa GBT, Senadhira DW (2000) Genes/QTLs affecting flood tolerance in rice. Theoretical and Applied Genetics 101(7): 10741081.
4. Suprihatno B, Coffman WR (1981) Inheritance of submergence tolerance in rice (Oryza sativa L.). SABRAO J 13: 98-102.

5. Haque QA, Hille D, Lambers R, Tepora NM, Cruz QD (1989) Inheritance of submergence tolerance in rice. Euphytica 41: 247-251.

6. Xu K, Mackill DJ (1996) A major locus for submergence tolerance mapped on rice chromosome. Mol Breed 2: 219-224.

7. Toojinda T, Siangliw M, Tragoonrung S, Vanavichit A (2003) Molecular genetics of submergence tolerance in rice: QTL analysis of key traits. Ann Bot 91: 243-253. 
8. Singh N, Dang T, Vergara G, Pandey D (2010) Molecular marker survey and expression analyses of the rice submergence-tolerance genes SUB1A and SUB1C. Theor Appl Genet 121(8): 1441-1453.

9. Sarkar RK, Reddy JN, Sharma SG, Ismail AM (2006) Physiological basis of submergence tolerance in rice and implications for crop improvement. Curr Sci 91: 899-906.

10. Das KK, Panda D, Sarkar RK, Reddy JN, Ismail AM (2009) Submergence tolerance in relation to variable floodwater conditions in rice. Environ Exp Bot 66: 425-434.

11. Pedersen O, Rich SM, Colmer TD (2009) Surviving floods: leaf gas films improve 02 and $\mathrm{CO} 2$ exchange, root aeration, and growth of completely submerged rice. Plant J 58: 147-156.

12. Fukao T, Xu K, Ronald PC, Bailey Serres J (2006) A variable cluster of ethylene response factor-like genes regulate metabolic and developmental acclimation responses to submergence in rice. Plant Cell 18: 2021-2034

13. Bailey Serres J, Fukao T, Ronald P, Ismail A (2010) Submergence tolerant rice: SUB1's journey from landrace to modern cultivar. Rice 3(2-3): 138147.
14. Ahmed A, Devadason ES, Al Amin AQ (2016) Implications of climate change damage for agriculture: sectoral evidence from Pakistan. Environmental Science and Pollution Research 23(20): 20688-20699.

15. Nishiuchi S, Yamauchi T, Takahashi H, Kotula L, Nakazono M (2012) Mechanisms for coping with submergence and waterlogging in rice. Rice 5(1): 2 .

16. Ju H van der Velde M, Lin E, Xiong W, Li Y (2013) The impacts of climate change on agricultural production systems in China. Climatic Change 120(1-2): 313-324.

17. Ahmed F, Rafii MY, Ismail MR, Juraimi AS (2016) The addition of submergence-tolerant Sub1 gene into high yielding MR219 rice variety and analysis of its BC2F3 population in terms of yield and yield contributing characters to select advance lines as a variety. Biotechnology \& Biotechnological Equipment 30(5): 853-863.

18. Zakaria ZA (2018) Sustainable Technologies for the Management of Agricultural Wastes. Springer Science and Business Media.

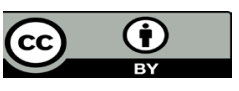

This work is licensed under Creative Commons Attribution 4.0 License

To Submit Your Article Click Here: Submit Article

DOI: $10.32474 /$ CIACR.2018.05.000220

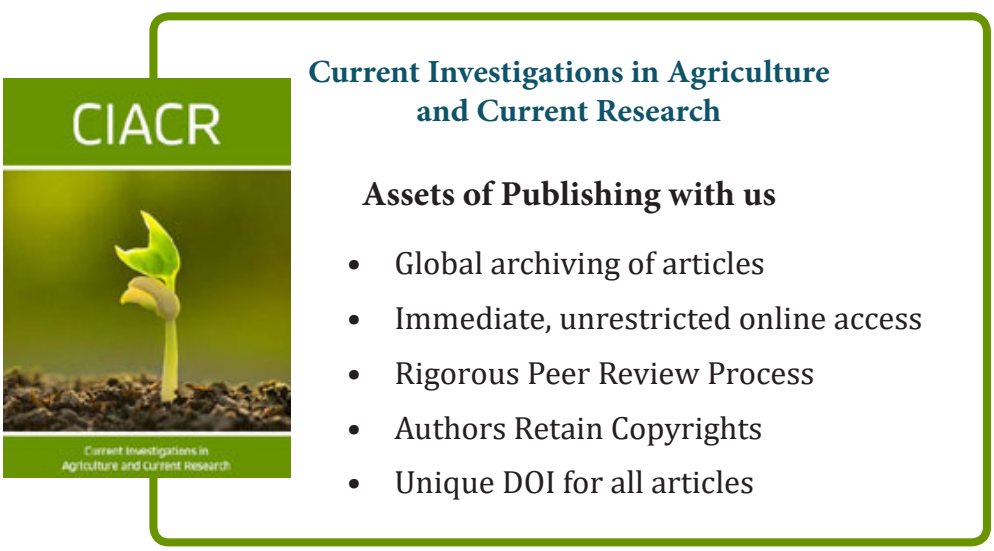

